\title{
LKKA STUDENTŲ PROFESINĖS VERTYBINĖS ORIENTACIJOS RENGIANTIS SPORTO PEDAGOGO KARJERAI
}

\author{
Audronė Dumčienè, Vilma Medišauskaitė \\ Lietuvos kūno kultūros akademija, Kaunas, Lietuva
}

\begin{abstract}
Audronė Dumčienė. Docentè socialinių (edukologijos) mokslų daktarè. Lietuvos kūno kultūros akademijos Sporto pedagogikos ir psichologijos katedros docentè. Mokslinių tyrimų kryptis — aktualios pedagoginès ir psichologinès problemos kūno kultūros ir sporto kontekste.
\end{abstract}

\section{SANTRAUKA}

Tyrimo tikslas - išanalizuoti LKKA I kurso studentu profesines vertybines orientacijas rengiantis sporto pedagogo karjerai.

Tiriamaja imti sudare 300 LKKA I kurso studentu. Tyrimui naudota adaptuota anketa, kuriq sudaro tokia profesine orientacija rodančios vertybiu grupès: saviaktualizacija, profesinè saviraiška, profesinès aspiracijos, socialumas, komfortas.

Tyrimas atskleide, kad visu LKKA fakultetu I kurso studentai prie svarbiausiu profesiniu vertybiu priskiria: pirmiausia - komforta, toliau - profesinę saviraiška, profesinę saviaktualizacija, socialuma. Profesines aspiracijas rodančios vertybès tarp svarbiausiu nepateko. Konstatuotas menkas būsimu sporto pedagogu socialumo lygis.

Pagal pasirinkimo dažni nustatytos šios svarbiausios LKKA I kurso studentu profesinès vertybès: geras atlyginimas (47\%); karjeros galimybès (44\%); rezultatu siekimas (41\%); nauju žiniu igijimas(40\%); mažai streso darbe (39\%). Ivairiu fakultetu pirmakursiai nurodo skirtingas svarbiausias profesines vertybes, ne tas pačias renkasi vyrai ir moterys.

Raktažodžiai: karjera, profesinès vertybès, profesinès vertybinès orientacijos.

\section{IVADAS}

I ntensyvejjanti globalizacija kelia vis didesnius specialistu kompetencijos reikalavimus, taigi tobulèti turi ir juos rengiančios institucijos. Atsirado būtinybe ìvardyti pagrindinius kompetencijos komponentus, jos lygmens požymius ir išdèstyti svarbiausias specialistu rengimo gaires.

Daugelis autoriu (Carnevale, 1991; Herr, 1990; Rhinesmith, 1992) akcentuoja šiuos svarbiausius profesinès kompetencijos komponentus: informacijos ir resursu valdymą, bendravimą ir bendradarbiavimą su žmonemis bei saviugdą visą gyvenimą. Be bazinio pasirengimo yra svarbūs problemų sprendimo ir sprendimu prièmimo gebėjimai, lankstumas, adaptyvumas, kūrybinis mąstymas, savimotyvacija ir gebejjimas reflektuoti.

Profesinè kompetencija igyjama bazinių kompetencijų (Bitinas, 2000) pagrindu.

Iki praejjusio šimtmečio devinto dešimtmečio buvo akcentuojamas rengimo(si) profesijai ir karjerai nacionalumas (Herr, 1990). Dèl globalizacijos vyksta ugdymo karjerai turinio ir tikslų, jos raidos pokyčiai. Pasak L. S. Zwerling (1992), ugdymas karjerai turètu būti liberalus ugdymas. J. Arnold (1997) ir H. Schuler (1995) nuomone, karjeroje labiau akcentuotinas asmeninis jos pobūdis. Pasak J. Arnold (1997), profesija yra tik kontekstas, kuriame rutuliojasi karjera.

Nors ugdymas karjerai kildinamas iš rengimo profesijai, bet rengimo karjerai teorinius pagrin- 
dus tik šeštame XX amžiaus dešimtmetyje padèjo amerikiečiai psichologai D. E. Super (2001), P. C. Cairo ir kt. (1996), D. V. Tiedeman (1983).

Karjera yra vienas iš svarbiausių asmenybès savimonès, savivertès, savigarbos, saviraiškos, socialinio statuso ir ekonominio gyvenimo šaltinių. Ji imanoma tiktai kaip individų ir socialinių sistemų (švietimo ir darbo organizacijų) sąveikos procesas. Šia prasme karjera galima laikyti susitarimu tarp išsilavinusio, gebančio kompetentingai veikti individo ir visuomenès, pripažistančios šios veiklos reikšmingumą, kokybę ir sutinkančios mokèti už tai tam tikromis vertybėmis (Bitinas, 2000).

Tyrimų duomenimis (Kučinskienė, 2003), kuo visuomenè labiau išsivysčiusi, tuo daugiau dèmesio ir investiciju joje skiriama ugdymui karjerai.

Literatūros šaltinių analizė parodè, kad karjerą ir rengimąsi jai apibūdinančios sampratos tebèra diskusijų lygmens, todèl šio tyrimo metu naudosimès tokiomis sampratomis:

- Karjera (Patton, McMahon, 2001) - visa žmogaus gyvenimo veikla, apimanti mokymąsi, darbą, laisvalaikị ir kitas sritis.

- Karjeros vertybių sistemą sudaro trys svarbiausi posistemiai: asmenybès vertybès, profesijos vertybès, organizacijos vertybès (Kučinskienè, 2003).

- Ugdymas karjerai - tikslingas visą gyvenima trunkantis procesas, apimantis švietimo, darbo organizacijų ir bendruomenès pastangas $(\mathrm{Ku}-$ činskiené, 2003).

- Rengimasis karjerai — tai nuolatinis žmogaus saviugdos procesas, kurio metu igyjama ir tobulinama sèkmingai karjeros plètotei būtina kompetencija (Kučinskienè, 2001).

- Rengimo karjerai tyrimai atliekami ir Lietuvoje (Kučinskienè, 2001, 2003; Pukelis, 2002; Sakalas, Šalčius, 1997; Stanišauskienė, Večkienè, 2000; Šernas, 2003), tačiau sporto pedagogu rengimas(is) karjerai aukštosios mokyklos ugdymo procese mažai tyrinètas.

Šalyje susiklosčiusi situacija, kad, pasak V. Šerno (2003), ,absolventų išsilavinimas neatitinka šiuolaikinès Lietuvos darbo rinkos reikalavimu, jei jie negeba susikurti darbo vietos, atiduoti duoklę šaliai, kuri suteikè jiems galimybę baigti mokslus". Taigi labai svarbu žinoti rengimo(si) sporto pedagogo karjerai aspektus.

Šiuo tyrimu siekiama išsiaiškinti studentu požiūri i esmines sporto pedagogo profesinès veiklos vertybes. Tyrimui buvo pasirinkti pirmakursiai, nes jų susidaryto sporto pedagogo veiklos ¿̇vaizdžio iš esmès dar nepakeitè studijos aukštojoje mokykloje.

Tyrimo tikslas - nustatyti LKKA I kurso studentu profesines vertybines orientacijas rengiantis sporto pedagogo karjerai.

Uždaviniai:

1. Ištirti studentų profesines vertybines orientacijas.

2. Nustatyti būsimujų sporto pedagogų profesinių vertybių skirstinį.

\section{TYRIMO OBJEKTAS IR METODAI}

Tyrimo objektas - LKKA pirmo kurso studentų vertybinès orientacijos rengimosi sporto pedagogo karjerai kontekste. Tiriamają imti sudare 300 studentų. Buvo apklausti 103 Sporto edukologijos (SE) fakulteto studentai (38 moterys, 65 vyrai); 82 Sporto biomedicinos (SB) fakulteto studentai (63 moterys, 19 vyrai); 115 Sporto technologijų ir turizmo (STT) fakulteto studentų (43 moterys, 72 vyrai).

Tiriant naudotasi Lietuvoje aprobuota (Gumuliauskienè ir Macaitienè, 2002) ir mūsų adaptuota (ivertinta sporto pedagogu rengimo specifika) Toronto universiteto Profesinès karjeros centro profesinių vertybių anketa, kurioje išskirtos tokias profesines vertybines orientacijas rodančios grupès: profesinè saviaktualizacija, profesinè saviraiška (šios dvi grupès išskirtos norint atlikti išsamesnę profesinès saviraiškos analizę), profesinès aspiracijos, socialumas, komfortas. Anketinis tyrimas vyko 2003 metais. Lyginamoji analizė atlikta trijuose LKKA fakultetuose - SE, SB ir STT. Anketiniai duomenys apdoroti matematinès statistikos metodais, naudojant EXCEL programą (procentinis skirstinys, skirtumų reikšmingumas pagal Pirsono $\chi^{2}$ kriterijų; reikšmingumo lygmuo $\mathrm{p}-0,05)$.

\section{REZULTATAI}

Respondentų atsakymų apie svarbiausias profesinę saviaktualizaciją, profesinę saviraišką, profesines aspiracijas, socialumą ir komfortą rodančias vertybes duomenys atitinkamai pateikti 1 , 2, 3, 4 ir 5 paveiksle.

Statistiniai skaičiavimai parodè (žr. 1 pav.), kad profesinę saviaktualizaciją rodančios vertybès „Būti kūrybingam“ ir „Darbas grupeje“" statistiškai 
patikimai $(\mathrm{p}<0,05)$ yra svarbesnès SE nei SB studentams. Vertybè „Viešas bendravimas“ statistiškai patikimai $(p<0,05)$ yra svarbesnè SE nei STT studentams. Vertybès „Būti kūrybingam“, „Meistriškumas“ ir „Darbas grupejje“ statistiškai patikimai $(\mathrm{p}<0,05)$ reikšmingesnès STT nei SB studentams. Vertybe „Intelektinis statusas“ statistiškai patikimai $(\mathrm{p}<0,05)$ svarbesnè SB nei STT studentams.

Svarbiausių profesinę saviraišką rodančių vertybiu duomenys pateikti 2 paveiksle.

Profesinę saviraišką rodančios vertybès „Rezultatų siekimas“ ir „Naujų žinių igijimas“ statistiškai patikimai $(p<0,05)$ yra svarbesnès SB nei SE ar STT studentams. Palyginus SE ir STT fakultetų studentų atsakymus apie saviraišką rodančias profesines vertybes, statistiškai patikimo skirtumo $(\mathrm{p}>0,05)$ nenustatyta. Tuo tarpu vertybè „Vadovavimas kitiems" STT studentams statistiškai patikimai $(\mathrm{p}<0,05)$ svarbesnè nei SB studentams.

Respondentų nuomonès dèl profesines aspiracijas rodančių svarbiausių profesinių vertybiu skirstinys pavaizduotas 3 paveiksle.

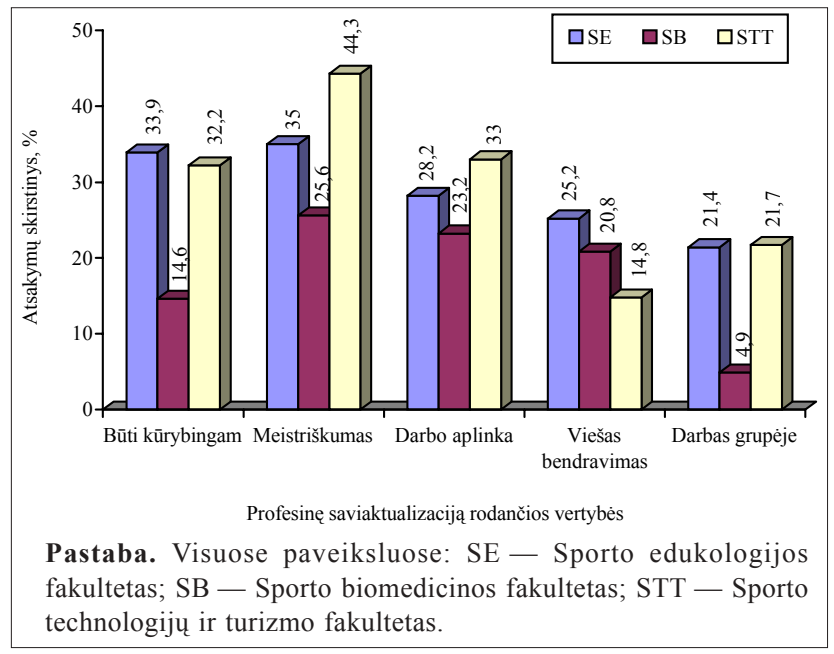

1 pav. Tiriamųjų skirstinys pagal vertybių aktualizacijas

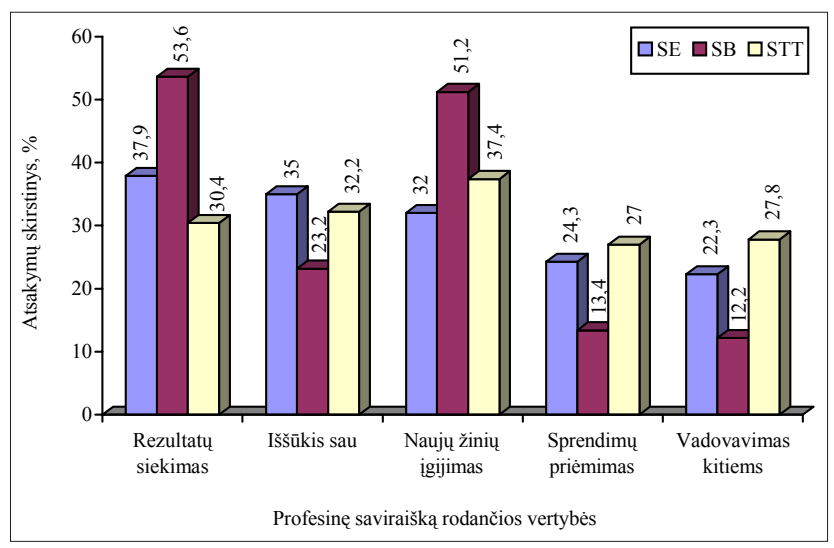

2 pav. Tiriamųjų skirstinys pagal profesinę saviraišką rodančių vertybių aktualizacijas
Profesines aspiracijas rodančios vertybės „Populiarumas“, „Ambicijos“ ir „Rizika“ statistiškai patikimai $(p<0,05)$ yra svarbesnès SE ir STT nei SB studentams. Be to, vertybès „Greito tempo aplinka“ ir „Konkurencija“ STT studentams statistiškai patikimai $(\mathrm{p}<0,05)$ svarbesnès nei SB studentams. Palyginus SE ir STT fakultetu studentų atsakymus apie profesines aspiracijas rodančias vertybes, statistiškai patikimo skirtumo $(p>0,05)$ nenustatyta.

Svarbiausių respondentų socialumą rodančių profesinių vertybių skirstinio duomenys pateikti 4 paveiksle.

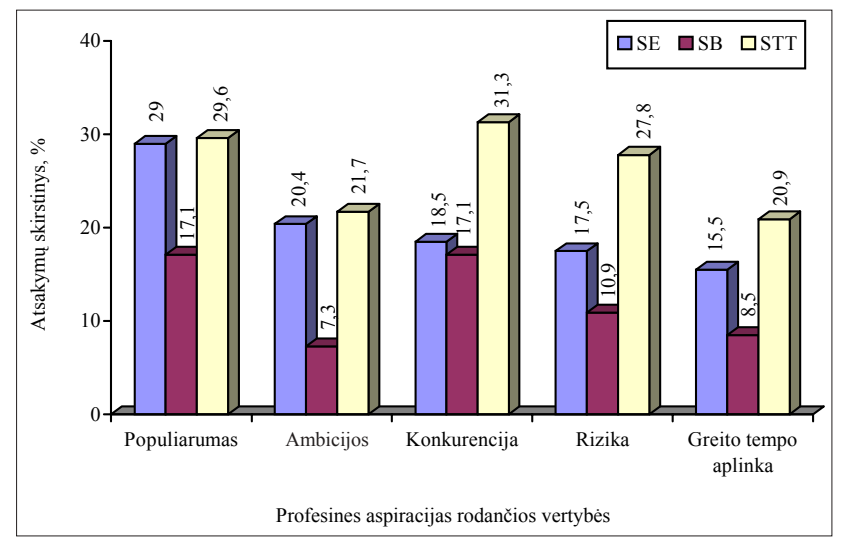

3 pav. Tiriamụjų skirstinys pagal vertybių aspiracijas

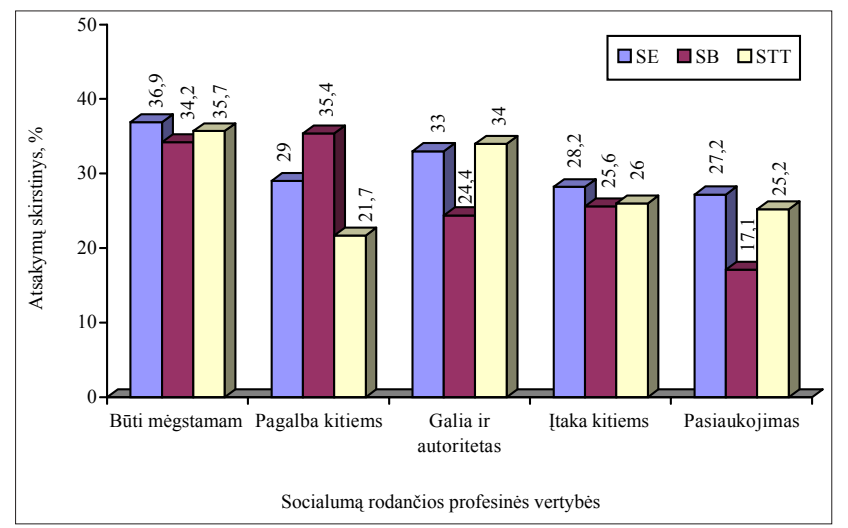

4 pav. Tiriamųjų skirstinys pagal socialumą rodančių vertybių aktualizacijas

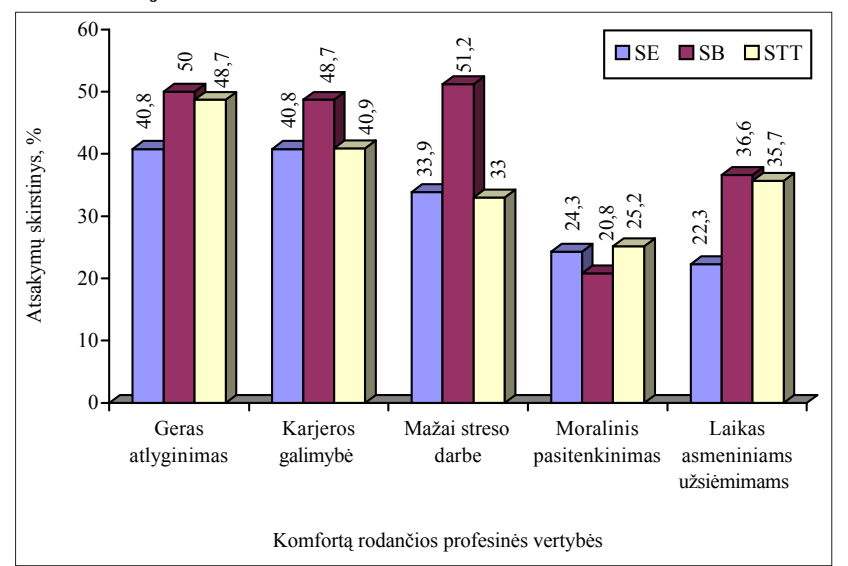

5 pav. Tiriamųjų skirstinys pagal komfortą rodančių vertybių aktualizacijas 
Statistinè analizè parodè, kad visų fakultetu studentu atsakymai apie socialumą rodančias svarbiausias profesines vertybes tarpusavyje statistiškai patikimai $(\mathrm{p}>0,05)$ nesiskiria.

Respondentų atsakymų apie svarbiausias komfortą rodančias profesines vertybes procentinis skirstinys pavaizduotas 5 paveiksle.

Atsakymų analizė parodè, kad komfortą rodanti vertybe „Mažai streso darbe“ statistiškai patikimai $(p<0,05)$ svarbesnè yra SB nei SE ir STT studentams, o vertybè „Laikas asmeniniams užsièmimams" statistiškai patikimai $(\mathrm{p}<0,05)$ yra svarbesnè SB ir STT nei SE studentams.

\section{REZULTATU APTARIMAS}

Išanalizavus visų fakultetų I kurso studentu profesinių vertybių orientacijas nustatyta, kad LKKA pirmakursiams reikšmès mažejjimo tvarka svarbiausios yra šios: „Geras atlyginimas“ (47\%); „Karjeros galimybe““ (44\%); „Rezultatų siekimas“ (41\%); „Naujų žinių igijimas“ (40\%), „Mažai streso darbe" (39\%). Tačiau fakultetuose šios nuomonès ịvairuoja. Taigi LKKA pirmakursių profesinès vertybinès orientacijos menkai atitinka šiuolaikines pasaulines tendencijas, nes, kaip nurodo P. Brown ir R. Scase (1997, p. 81), dabar reikia turèti „karjeros portfelyje: būtinas žinias, igūdžius, patirtị ir kontaktus, kurie, beje, nèra pastovūs“. Tyrimo rezultatai liudija, kad per pirmuosius pirmakursių rengimosi sporto pedagogo karjerai studijų metus tarp svarbiausių profesiniu vertybiu jie nenurodè tų, kurios iš esmès lemia profesinę veiklą. I LKKA, kaip ir kitas aukštąsias mokyklas, matyt, istoja abiturientai, neturintys aiškių profesinių vertybinių nuostatų, nes, kaip rodo tyrimai (Stanišauskienè ir Večkienė, 2000), bendrojo lavinimo mokyklose egzistuojančios rengimosi karjerai prielaidos yra nepakankamos ir netolygios. Tvirtu profesiniu vertybiniu nuostatu nebuvimą rodo ir tai, kad stojantieji prašymuose nurodo po kelias aukštąsias mokyklas ir keliolika pageidautinu specialybių.

Kita vertus, gero atlyginimo iškèlimas i pirmą vietą rodo šalyje dirbančių pedagogų nuostatas, nes 2003 metais 63,6\% jų nurodè esą patenkinti atlyginimu (Šileika ir kt., 2003). LKKA studentu profesinių vertybinių nuostatų neatitikimas pasaulinių tendencijų iš esmès atitinka šias nuostatas, esančias šalyje, nes net $63,6 \%$ pedagogų mano, kad profesinis pasirengimas pakankamas, tačiau net $90,9 \%$ nurodo nepakankamą praktini pasi- rengimą (ten pat).

Sporto edukologijos fakultete jos išdèstytos taip: „Karjeros galimybès“; „Geras atlyginimas“ (po 40\%); ,Rezultatų siekimas“ (37,9\%); ,Būti mègstamam“ (36,9\%); „Meistriškumas“; „Iššūkis sau“ (po 35\%); ,Mažai streso darbe“ (33,9\%). Šie tyrimo duomenys iš esmès nesiskiria nuo kitu autorių (Gumuliauskienė ir Macaitienè, 2002) gautu rezultatu.

Sporto biomedicinos fakultete: „Rezultatų siekimas“ (53,6\%); „Naujų žiniu igijimas“; „Mažai streso darbe“ (po 51,2\%); „Geras atlyginimas“ (50\%); „Karjeros galimybès“ (48,7\%); „Laikas asmeniniams užsièmimams" $(36,6 \%)$.

Sporto technologijų ir turizmo fakultete: „Geras atlyginimas" $(48,7 \%)$; „Meistriškumas“ $(44,3 \%)$; „Karjeros galimybės“ (40,9\%); „Naujų žiniu igijimas“ (37,4\%); ,Laikas asmeniniams užsièmimams“"; „Būti mègstamam“; ,Dirbti nepriklausomam" (po 35,7\%). Gauti rezultatai neprieštarauja A. P. Carnevale (1991) mintims apie plačios profesinių vertybių skalès svarbą siekiant karjeros greit kintančioje aplinkoje. Tą patvirtina ir S. Rhinesmith (1992), pabrèždamas globalios mąstysenos svarbą, gebèjimą suvokti reiškinius plačiau.

Analizuojant vertybių grupes nustatyta, kad būsimieji sporto pedagogai labiausiai vertina profesines vertybes, rodančias komfortą. Tarp svarbiausių vertybių pagal pasirinkimo dažnio procentinę išraišką STT ir SB fakultetų studentai nurode keturias iš jų, o $S E$ - tris. Atitinkamai vertybes, rodančias profesinę saviraiška, SE ir SB fakultetų respondentai nurodè dvi, o STT - vieną. Po vieną vertybę, rodančią profesinę saviaktualizaciją, nurodè tik STT ir SE fakultetu studentai. Tik vieną vertybę, rodančią socialumą, nurodè SE fakulteto studentai. Deja, ị svarbiausiu profesinių vertybiu rinkinius nepateko nè viena, rodanti profesines aspiracijas. Tenka konstatuoti, kad būsimi sporto pedagogai, kurių profesija tiesiogiai siejasi su rūpinimusi žmonemis ir pagalba jiems, sveikos gyvensenos propagavimu, yra labai prasto socialumo lygio ir turi menkas profesines ambicijas. Aiški profesinių vertybių nuostata yra labai svarbi vertinant karjeros perspektyvas, tai patvirtina ir kitu autorių tyrimo rezultatai (Cairo et al., 1996).

Šiek tiek netikètas tyrimo rezultatas buvo tai, kad STT fakultete, kuriame studijuoja gana daug sportininkų (dalis iš jų - būsimi treneriai), tarp penkių svarbiausių vertybių „Rezultatų siekimo“ 
nebuvo. Tuo tarpu SB fakulteto studentai šią vertybę nurodydavo dažniausiai, o SE ją i̇vardydavo antra pagal svarbą.

Tik 12\% tiriamujų prie svarbiausių profesiniu vertybiu priskyrè norą dirbti grupeje, ir tai neatitinka šiuolaikinių profesinès veiklos tendenciju (Walker, 1992).

Vyrai ir moterys pasirinko skirtingas svarbiausias vertybes. STT fakulteto moterims svarbiausia profesiné vertybè — „Meistriškumas“, vyrams — „Laikas asmeniniams užsièmimams“. SE fakultete: moterims - „Naujų žiniu igijimas“, vyrams — „Rezultatu siekimas“. SB fakultete: moterims — „Karjeros galimybės“, vyrams „Rezultatu siekimas“ (šis skirtumas statistiškai nereikšmingas, $p>0,05$ ).

Palyginus SE ir STT fakultetų vyru profesiniu vertybiu ivertinimo rezultatus nustatyta, kad SE fakulteto studentams „Rezultatu siekimas“ yra svarbesnè vertybė $(49,2 \%)$ nei STT fakulteto studentams (15,2\%) (skirtumas statistiškai patikimas, $\mathrm{p}<0,05)$. SB fakulteto respondentams vyrams „Naujų žiniu igijimas“ yra svarbesnè vertybė $(57,9 \%)$ nei STT $(19,4 \%)$ ir SE $(7,8 \%)$ fakultetu vyrams $(p<0,05)$. Palyginus moterų atsakymų rezultatus pastebèta, kad „Rezultatų siekimas“ yra svarbesnè profesinè vertybe SB fakulteto studentèms $(42,9 \%)$ nei būsimoms sporto edukologèms $(18,4 \%)(\mathrm{p}<0,05)$. Tačiau „Pagalba kitiems“ yra reikšmingesnè profesinè vertybė SE fakulteto studentèms $(55,3 \%)$ nei SB fakulteto studentèms $(30,2 \%)$. Atkeiptinas dèmesys i tai, kad „Pasi- aukojimas" būsimoms sporto edukologèms statistiškai patikimai svarbesnis $(51,2 \%)$ nei SB fakulteto studentèms. Taigi galima teigti, kad skirtingų fakultetų pirmakursiai išskiria ne tas pačias svarbiausias profesines vertybes, be to, nevienodas profesines vertybes renkasi vyrai ir moterys.

Tyrimo rezultatai rodo, kad tikslinga periodiškai apklausti studentus ir duomenis panaudoti valdant studiju procesa, kaip tai daroma kituose universitetuose (Wickwire, 1995).

\section{IŠVADOS}

1. Visu LKKA fakultetų I kurso studentai prie svarbiausių profesiniu vertybiu priskiria: pirmiausia - komfortą, toliau — profesinę saviraišką, profesinę saviaktualizaciją, socialumą. Profesines aspiracijas rodančios profesinès vertybès tarp svarbiausių nepateko. Konstatuotas menkas būsimų sporto pedagogų socialumo lygis.

2. LKKA I kurso studentų profesinių vertybiu eiliškumas neatitinka pasaulinès darbo rinkos šiuolaikinių tendenciju.

3. Respondentu svarbiausių profesinių vertybiu pasirinkimo dažnio seka tokia: „Geras atlyginimas“ (47\%); „Karjeros galimybé“ (44\%); „Rezultatų siekimas“ (41\%); „Nauju žiniu igijimas“ (40\%); „Mažai streso darbe“ (39\%).

4. Pastebètas tam tikras moterų ir vyrų vertybiniu orientacijų skirtumas.

\section{LITERATŪRA}

Arnold, J. (1997). Managing Careers into the $21^{\text {st }}$ Century. London: Paul Chapman Publishing Ltd.

Bitinas, B. (2000). Ugdymo filosofija. Vilnius: Enciklopedija.

Brown, Ph. \& Scase, R. (1997). Universities and employers: Rhetoric and reality. The Postmodern university. In A. Smith and F. Webster (Eds.), Contested Vision of Higher Education in Society. London.

Cairo, P. C., Kritis, K. J. \& Myers, R. A. (1996). Career assessment and the Adult Career Concerns Inventory. Journal of Career Assessment, 4, 198-204.

Carnevale, A. P. (1991). America and the New Economy. Alexandria, VA: American Society for Training and development.

Gumuliauskienè, A. ir Macaitienè, R. (2002). Būsimuju pedgogu profesinès vertybės. Peadgogika, 61, 83-90.

Herr, E. L. (1990). Employment counseling in a global economy. Journal of Employment Counseling, 27 (4), $147-159$.

Kučinskienè, R. (2003). Ugdymo karjerai metodologija.
Klaipėda: KU.

Kučinskienė, R. (2001). Ugdymas karjerai — švietimo aktualija pasaulyje ir Lietuvoje. Pedagogika, 43, 40-50.

Patton, W., McMahon, M. (2001). Career Development Programs: Preparation for Life Long Career DecisionMaking. Melbourne: ACER. P. 13.

Pukelis, K. (2002). Karjeros projektavimo gebejjimai žinių visuomeneje: nauji iššūkiai profesiniam konsultavimui ir karjeros planavimui. Profesinis rengimas: tyrimai ir realijos, 6, 24.

Rhinesmith, S. (1992). Global mindsets for global managers. Training and Development, 46 (10), 63-68.

Sakalas, A. ir Šalčius, A. (1997). Karjeros valdymas. Kaunas: Technologija.

Schuler, H. (Hrsg.) (1995). Lehrbuch Organisationspsychologie (2. korr. Aufl.). Bern: Huber.

Stanišauskienė, V. ir Večkienė, N. (2000). Rengimasis karjerai transformacijų laikotarpiu: Lietuvos gimnazijose egzistuojančiu prielaidų analizé. Socialiniai mokslai, $1(22), 84-90$. 
Super, D. E. (2001). Opportunities in Psychology Careers. Contemporary Books.

Šernas, V. (2003). Profesinio elito ugdymo gerinimo būdu paieškos. Prieiga per internetą: http://www.vdu.lt/ alearning2003/II\%20Dalis/Sernas_lt_kalb.doc.

Šileika, A., Gruževskis, B., Čèsnaitè, B. ir kt. (2003). Specialistu poreikis. Universitetu absolventu konkurencingumas darbo rinkoje darbo jegos pasiūlos ir paklausos kontekste. 2003 metu tyrimas. Prieiga per internetą: http:/ / www.mokslas.1t/index.cgi?menu_item= specialist_needs_forecast

Tiedeman, D. V. (1983). Flexible filing, computers and growing. The Counseling Psychologist, 11 (4), 33-48. Walker, J. W. (1992). Career paths in flexible organisation. In D. Montross and C. Shinkman (Eds.), Career Development: Theory and Practice. Springfield. IL: Charles C. Thomas.

Wickwire, P. N. (1995). Career Education: That Works in Programs, Practices and Publications. California: Clearing Hause Company.

Zwerling, L. S. (1992). Liberal learning and the world of work. New Directions for Adult and Continuing Education, $53,99-113$.

\title{
THE VALUES OF PROFESSIONAL ORIENTATIONS OF STUDENTS AT THE LITHUANIAN ACADEMY OF PHYSICAL EDUCATION DURING THEIR PREPARATION FOR THE CAREER OF A SPORT PEDAGOGUE
}

\author{
Audronė Dumčienė, Vilma Medišauskaitė \\ Lithuanian Academy of Physical Education, Kaunas, Lithuania
}

\begin{abstract}
The purpose of the research - to define the values of professional orientations of freshmen during their preparation for the career of a sport pedagogue at LAPE.

The investigated sample were 300 freshmen at LAPE. In the research the adapted questionnaire was applied, in which there were groups of values, reflecting such values of professional orientations: selfactualization, professional self-expression, professional aspiration, sociability and comfort.

The results of the research have shown that the freshmen of all faculties at LAPE most frequently have attributed these values as the most important professional values: 1. Comfort; 2 . Professional self-expression; 3. Professional self-actualization; 4. Sociability. Professional values, reflecting professional aspiration, have not been marked as the most important. Low level sociability of the future sport pedagogues has been stated.

The following professional values were detected as the most important, referring to the freshmen's choice: good salary (47\%) opportunities of career (44\%); aspiration for high results (41\%); mastering of new knowledge (40\%); low level of stress in a workplace (39\%).

The most important professional values vary in the mind of freshmen in different faculties, besides the values were different between women and men.
\end{abstract}

Keywords: career, professional values, values of professional orientations.

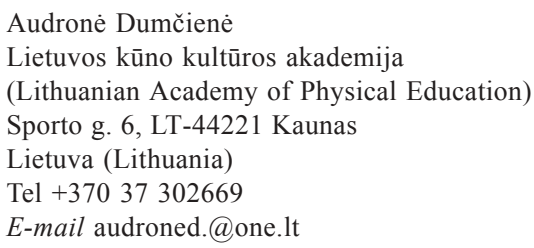

(Lithuanian Academy of Physical Education)

Sporto g. 6, LT-44221 Kaunas

Tel +370

E-mail audroned.@one.1t 